Erratum

\title{
Erratum: Hoover, K.D. 2020. The Discovery of Long-Run Causal Order: A Preliminary Investigation. Econometrics 8: 31
}

\author{
Kevin D. Hoover 1,2
}

1 Department of Economics, Duke University, Durham, NC 27708, USA; kd.hoover@duke.edu;

Tel.: +1-919-660-1876

2 Department of Philosophy, Duke University, Durham, NC 27708, USA

Citation: Hoover, Kevin D. 2021 Erratum: Hoover, K.D. 2020. The Discovery of Long-Run Causal Order: A Preliminary Investigation.

Econometrics 8: 31. Econometrics 9: 7. https://doi.org/10.3390/econometrics 9010007

Received: 4 February 2021

Accepted: 4 February 2021

Published: 18 February 2021

Publisher's Note: MDPI stays neutral with regard to jurisdictional claims in published maps and institutional affiliations.

Copyright: (c) 2021 by the author. Licensee MDPI, Basel, Switzerland. This article is an open access article distributed under the terms and conditions of the Creative Commons Attribution (CC BY) license (https:/ / creativecommons.org/licenses/by/ $4.0 /)$.
The author would like to make the following correction to the article by Hoover (2020):

The symbol " $\mapsto$ ", first defined as "is weakly exogenous for" in the first line of the third paragraph of Section 4.3, was inadvertently and systematically converted in production to the symbol " $\alpha$ ". Every instance in which symbol " $\alpha$ " is used to denote weak exogeneity should be changed to " $\mapsto$ ".

The Editorial Office would like to apologize for any inconvenience caused to the readers by this change. The change does not affect the scientific results. The manuscript will be updated and the original will remain online on the article webpage.

Conflicts of Interest: The author declares no conflict of interest.

\section{Reference}

Hoover, Kevin D. 2020. The Discovery of Long-Run Causal Order: A Preliminary Investigation. Econometrics 8: 31. [CrossRef] 